\title{
The development of guidelines to improve the interpersonal communication of students in preparation for entering the workforce thought information services
}

\author{
Fitri Yunizar', A. Muri Yusuf ${ }^{2}$, Yarmis Syukur ${ }^{3}$ \\ ${ }^{123}$ Universitas Negeri Padang \\ *Corresponding author, e-mail: fitri010119912@gmail.com
}

\begin{abstract}
Communication is very important in the world of work. With communication, individuals can socialize with other individuals well. But in reality, there are still many individuals who have not been able to communicate well. Vocational High School (SMK) is a secondary education that prepares students to become professional workers. Therefore, it is expected that SMKs can produce students who understand and can communicate well. Interpersonal communication is sending messages from individuals to other individuals with direct effects and feedback. This research is a research development that aims to develop guidelines to improve interpersonal communication of vocational high school students in entering into the world of work through information services. The sample selection uses purposive sampling. The results of this study indicate a material feasibility test score of 78.9 with a feasible category and expert judgment on the appearance of an appearance with an average score of 85.7 with a very feasible category. As for the practicality test an average score of 92.8 with a high category.
\end{abstract}

Keywords: Interpersonal Communication

\section{Introduction}

Technology is increasingly developing, bringing changes in almost all aspects of human life. Yahya argues that the development of communication, genetics, robotics, artificial intelligence, nanotechnology, is a sign of the presence of the industrial revolution 4.0 (Idrus, 2018). The era of industrial revolution 4.0 is a term coined in Germany in 2011 which was marked by the digital revolution (Satya, 2018). Before industry 4.0 many countries including Indonesia had experienced unemployment problems (Widjayanto, 2018). The era of industrial revolution 4.0 must be addressed properly by individuals, if not then individuals will not be able to compete so that the industry will be able to sever employment relations (Idrus, 2018).

Occupation Is an activity of doing something. Socially, work is seen as an activity carried out to realize public welfare, especially for families and communities and to maintain and 
develop life (Renita, 2006). Work is a projection of an individual's ability for the work he has chosen, as a task of life, career and individual responsibility for the career and work entrusted (Yarmis, 2012). This is the basis of how work is very important for the survival of individuals. Therefore, preparation to enter the workforce must be done by students to be able to have a good career. Preparation comes from the word "ready" which is defined as an action or design to do something. So, it can be concluded that work preparation is an action, design, effort, effort made to enter the workforce. One of the skills that must be possessed by individuals in preparation for entering the workforce is communication skills (Sukardi, 1993).

DeVito (2011) explains interpersonal communication is the sending of messages from individuals and being received by other individuals with direct effects and feedback. Liliweri (1991) argues that communication between communicate and communication a very effective effort to change the nature, opinions, and behavior of individuals because it is dialogic in the form of direct conversations and feedbacks in which the communican at that time also responds. From some of the definitions above, it is concluded that interpersonal communication is the sending of messages between communicator and communicant or interpersonal, whether it's one individual with another individual or an individual with a group, which causes effects and direct feedback by the communicant so that it is very effective in changing the nature, opinions, and behavior of individuals.

In Indonesia, the institution that prints skilled workers is Vocational High School (Fadli, Alizamar, Afdal 2017). Vocational school is a secondary education that prepares students primarily to become secondary workers in certain fields (Law Number 20, 2003 Article 15 concerning National Education System). This opinion is also suggested by Fadli et al (2017) that the expected results of SMK graduates are that graduates will be able to compete in the workforce and create new work fields (Fadli, Alizamar, Afdal 2017). Students are given knowledge in the form of theories and practical skills, as well as patterns of social behavior and national insight (Schippers, 1993). Students are also equipped with better soft skills developed by educational institutions (Hagman, 2003) either through integrated learning (Utaminingsih, Yulianto, \& Aulia, 2013) or with extracurricular and others (Wagiran, 2008; Utaminingsih et al., 2013).

Besides, judging from the elaboration of competency standards and basic competencies of SMKs in the Hospitality Accommodation Department in the Ministry of Education (2006) on SI and SKL, it is very clearly written that one of the competency standards is to be able to communicate well in the workplace. This competency must be owned by students because of the many knowledge and skills needed in industrial travel, courtesy in communication is one of the most important factors (Dharmayanti, 2013). The explanation above is in line with Permendiknas No. 23/2006 Article 18 and Article 22 regarding Education Unit Graduates' Competency Standards (SKL-SP) which state that one of the SMK graduation standards is that students can communicate orally and write effectively and politely. Article 22 also explained that the other passing standards are to show listening, reading, writing and speaking skills in Indonesian and English. Education does not only prepare individuals for the future but also how to prepare individuals to be able to live (B Uno \& Lamatenggo, 2014).

Improving students' interpersonal communication in preparation for entering the workforce has been carried out by the Guidance and Counseling teacher by providing information services on communication in general. But the Guidance and Counseling teacher still uses the lecture method and does not yet have an effective medium specifically the 
Vocational High School (SMK) that can be used to improve general communication through information services.

Information services are services provided to meet the lack of information needed by individuals (Prayitno, 2012). Sukardi explained that information services are services that enable students to receive and understand information that is used as material for consideration and daily decision making as students, family members and the community (Kusri, 2016). From some of the above understanding, it can be concluded that information services are services that seek to equip individuals with knowledge about data and facts in the field of school education, work fields, and the field of social personal development related to the function of understanding. Therefore, information services with guidance are expected to be able to improve interpersonal communication. Many studies describe the importance of interpersonal communication skills for students. As research conducted by Nuraeni (2010) with the results, there is a significant relationship between self- confidence with the anxiety of interpersonal communication students. Individuals will not be able to believe in themselves if interpersonal communication is not good. Munandar (2012) explains that the factors that cause individual job satisfaction are one of them is the social support of colleagues and communication. Collins explains that workers with the poor social atmosphere are characterized by a lack of interpersonal communication with coworkers having a high level of job dissatisfaction, a high level of work absenteeism, as well as showing physical, psychological, and stressful behavioral symptoms (Collins, 2013).

Nwagbara explains that communication between colleagues and superiors could have an effective impact on reducing the number and intensity of employee turnover ("The Impact of Effective Communication on Employee Turnover Intention at First Bank of Nigeria," 2013). Moghimi (2013) shows that interpersonal communication between managers and subordinates can improve work performance in both. Ramaraju states that interpersonal communication can increase a sense of understanding and good support among fellow communicants, the support provided by coworkers is expected to have a positive relationship and increase employee job satisfaction (Nwagbara, Oruh, Ugorji \& Ennsra, 2013).

Ruben \& DeAngelis (1998) group the competencies needed by individuals to be successful in their career and life, namely personal, communication, organizational, international/intercultural and domain competencies. Whereas the skills most sought after by employment are communication skills, integrity/honesty, interpersonal skills, motivation/initiative, strong work ethics, working in teams, computer skills, analytical, flexibility/adaptability, and detail-oriented (Puliam 2008; Utaminingsih, 2012). Individuals who can communicate effectively will be easy in resolving conflicts, especially conflicts with others, and they will be good when getting into the workforce (Sridasweni, A.Muri Yusuf, 2017). Referring to the results of the research described earlier, it can be concluded that interpersonal communication skills are very important in the workforce. Given the importance of interpersonal communication skills for Tourism Vocational students, the writer is interested in developing guidelines for improving interpersonal communication of vocational high school students in preparation for entering the workforce through information services.

\section{Method}


This research is research \& development, using the development process according to the ADDIE model which includes Analyze, Design, Development, Implementation, and Evaluation (in Molenda, 2003). Product development activities carried out by researchers only reached the stage of small group testing or product usage test by the guidance and counseling teacher or counselor. The test subjects in this study consisted of experts in the field of guidance and counseling consisting of six people to conduct a feasibility test that is three people judging in terms of appearance and three people in terms of material. The feasibility test by four guidance and counseling teachers as well as holding a Focus Group Discussion (FGD) to four guidance and counseling/counselor teachers and the usability test to three practitioners namely guidance and counseling teacher or counselor to assess the usability of the product that has been designed.

Data collection in this study uses Likert and Thurstone scales, questionnaires, and FGD. The collected data is then processed descriptively to illustrate the characteristics of each respondent's score distribution by establishing a category from the product trial results. Besides, the study also uses nonparametric statistics by utilizing the Kendall's W. Concordance Coefficient Test

\section{Results and Discussion}

Based on the results of the study, it can be revealed that through the expert feasibility test at the development stage towards improving interpersonal communication of vocational high school (SMK) students in preparation for entering the workforce through information services, the overall average value of the material eligibility expert was 78.9 with an appropriate category and an average expert assessment for the feasibility test display of 85.7 with a very feasible category to be implemented in Vocational Schools (Vocational Schools) after it was perfected according to validator input so that a guideline was produced to improve interpersonal communication of vocational high school students (Vocational Schools) in preparation for entering the workforce through information services as a product result and ready to be implemented and tested for use in schools by the guidance and counseling teacher or counselor. Furthermore, based on the results of Kendall W's concordance coefficient test, the assessment of material experts obtained a probability of 0.01 and from the display, experts obtained a probability of 0.008 . Thus, it can be said that there is harmony/appropriateness of the assessment of the three material experts and the appearance of the research product.

Next, from the results of the feasibility test conducted on four guidance and counseling teachers, obtained an average value of 93.9 with a very feasible category and the results of Kendall's W's Concordance Coefficient of 0.004. Next, a focus group discussion (FGD) was conducted, and the results obtained from the FGD were an average of 95.4 in the very feasible category, and Kendall's W's concordance W coefficient test of 0.009. At the implementation stage by the guidance and counseling teacher or counselor, the usability test results are obtained with an average value of 92.8 with a high category. This means that the assessment given by the guidance and counseling teacher or counselor regarding the guidelines arranged can be applied or used by the guidance and counseling teacher or counselor in the school. Then through Kendall W's concordance coefficient test, a probability of 0.015 was obtained. This means that there is alignment/appropriateness of the assessment of the three guidance and counseling or counselor teachers on research products. The product development in this research resulted in a prototype guide to improve the interpersonal communication of 
vocational high school (SMK) students in preparation for entering the workforce through information services in conducting counseling services.

\section{The level of eligibility of the guide improves personal communication of vocational high school (SMK) students in preparation for entering the workforce through information services}

From the results presented in the development stage, it is known that the guidelines compiled have reached a category appropriate or the contents of the guide and a category very suitable for display. The assessment of material aspects includes the contents of the guide, the relevance of the material, RPL, reference frame and general guidelines, while the appearance or appeal of the guide includes the design of the cover, typeface, layout, punctuation and other things about the appearance of the guide that has been compiled. That is, the material and overall appearance of the developed guide is already interesting if seen the appearance and is good and easy to understand the material.

Given the importance of interpersonal communication for vocational high school students in the tourism family, guidance and counseling teachers are expected to provide career services, one of which is by providing information about interpersonal communication in preparation for entering the workforce. This is supported by the views of the elaboration of competency standards and basic competencies of the Vocational High School (SMK) majoring in Hospitality Accommodation (Clump of Tourism) in Permendiknas (2006) about SI and SKL, it is very clearly written that one of the competency standards is to be able to communicate well with colleagues at work. This competency must be possessed by students because of the vast amount of knowledge and skills needed in industrial travel, courtesy in communication is one of the most important factors (Dharmayanti, Gading, Lestari, 2017).

The Usability Level of the guide improves interpersonal communication of vocational high school (SMK) students in preparation for entering the workforce through information services

The implementation of the guidelines improves interpersonal communication of vocational high school (SMK) students in preparation for entering the workforce through the compiled information services that have reached an adequate level of use. The steps in the RPL have been adjusted to the powerpoints that have been designed so that the guidance and counseling teacher or counselor can easily apply them. Worksheets, process evaluation sheets, and material evaluation sheets are also equipped with assessment guides so that guidance and counseling teachers can easily evaluate students' understanding of the guidance material provided through information services. This is relevant to the opinion of Mulyasa (2005) which states that the guide as a learning tool or tool that contains learning packages in which contained material, methods, and ways of evaluating that are designed systematically and attractively to achieve the expected learning goals.

The use of this guide will also direct students to find their concepts so that the service using the guide will be more focused on students while the guidance and counseling teacher or counselor only functions as a facilitator. This is following the opinion of Arsyar (2011) that by using the guide, students can learn at their own pace and learn more independently. Thus, the research product in the form of a guide to improving interpersonal communication of vocational high school students in preparation for entering the workforce through practical information services can be used by guidance and counseling teachers or counselors at school 


\section{Conclusion}

Based on the results of research and discussion, it can be concluded that the guide to improve the interpersonal communication of vocational high school students in preparation for entering the workforce through information services is in the category of material worth and very suitable for display. This means that experts agree that the guidelines developed are feasible to be implemented or used by guidance and counseling teachers or counselors in providing information services to students. The level of use of guidance and counseling guides to improve students' interpersonal communication skills is in the high category. This means that guidance and counseling guidance to improve interpersonal communication skills can be used as a medium in guidance and counseling services.

The product developed is in the form of a special guide to be implemented in vocational high school students in the tourism family. The use of guidelines for non-vocational high school students in tourism clusters requires the right formulation following with the characteristics of these students. the guidelines developed are limited to small group trials, for this reason, field trials need to be carried out to see the effectiveness of using the guidelines to improve interpersonal communication skills of vocational high school students in preparation for entering the workforce through information services, and the implementation of these guidelines will be carried out with both if the guidance and counseling teacher or counselor has complete supporting tools and is expected to always complete and plan carefully before providing services to students.

\section{References}

Asyhar, R. (2011). Kreatif Mengembangkan Media Pembelajaran. Jakarta: Gaung Persada Press.

B. Uno \& Lamatenggo. (2014). Teori kinerja dan pengukuran. Jakarta: Bumi Aksara

Collins, S. (2013). Teknik role playing dalam meningkatkan interpersonal siswa smk. Pendidikan Dan Pengajaran, 46(11), 3.

DeVito, J. A. (2011). Komunikasi antarmanusia. Terjemahan Agus Maulana. Pamulang: Karisma Publishing Group.

Dharmayanti, Gading, Lestari. (2017). Pelatihan merancang media audio visual berbasis performance assesment dalam pelaksanaan mahasiswa jurusan bk fip undiksha. International Journal of Community Service Learning. vol 1, 52-58

Dharmayanti, P. A. (2013). Teknik role playing dalam meningkatkan keterampilan komunikasi interpersonal siswa SMK. Jurnal Pendidikan dan Pengajaran, 46(3)

Fadli , Alizamar, Afdal. (2017). Persepsi siswa tentang kesesuaian perencanaan arah karir berdasarkan pilihan keahlian siswa sekolah menengah kejuruan. Konselor, 6(2), 74-82. https://doi.org/10.24036/02017627578-0-00

Haggman, (2003). An integrative model of competency development, training design, assesment center, and multi - Rater Assesment; Advance in Human Resources; Vol 8 No. 2, May 2006; pp 265- 282

Idrus, S. (2018). Perspektif sumber daya manusia pariwisata di era revolusi industri 4 . 0 screen to screen, dengan dalih mudah dan efesien . P engembangan genetika , (November), 587-594.

Kemendikbud. (2018). Spektrum keahlian sekolah meengah kejuruan (SMK)/madrasa aliyah kejuruan (MAK) 
Liliweri. (1991). Memahami peran komunikasi massa dalam masyarakat. Bandung: Citra Aditya Bakti.

Munandar, A. S. (2012). Psikologi industri dan organisasi. Depok: UI-Press.

Molenda, M. (2003). "In Search of the Elusive ADDIE Model". Jurnal Performance Improvement, 42 (3): 34-36.

Moghimi, S. F., Chamanzamin, M. R., Shaghaghi. (2013). The relationship between communication skill and job performance of the employees, fire managers of Rasht City. Journal of Islamic Azad University, 3 (2) 60 - 65.

Mulyasa, E. (2005). Kurikulum Berbasis Kompetensi: Konsep, karakteristik, dan implementasi. Bandung: Remaja Rosdakarya.

Nuraeni, N., Fitrajaya, A., \& Setiawan, W. (2010). Efektivitas penerapan model pembelajaran generatif untuk meningkatkan pemahaman siswa dalam mata pelajaran teknologi informasi dan komunikasi. Makalah. Bandung: UPI-Bandung.

Nwagbara, E. S., Ugorji, C., \& Ennsra, M. (2013). The impact of effective communication on employee turnover intension at first bank of nigeria. Economic Insights- Trends and Challenges, II(4), 13-21.

Permendiknas. (2006). Tentang SI dan SKL . Jakarta: Sinar Grafika.

permendikbud. (2014). Permendikbud nomor 111 tentang bimbingan dan konseling pada pendidikan dasar dan pendidikan menengah. Jakarta: Menteri Pendidikan Nasional.

Prayitno. (2012). Jenis layanan dan kegiatan pendukung konseling. Padang: Universitas Negeri Padang.

Renita. (2006). Bimbingan dan Konseling SMA 1 untuk Kelas X. Jakarta: Erlangga.

Ruben \& DeAngelis, (1998). Closing the gap between what industry needs and what HE provides. Education Training; Volume 42. Number 9. 2000: pp. 168-187: MCB University Press.

Satya, Venti Eka. (2018). Strategi Indonesia Menghadapi Industri 4.0. Buletin info Singkat. Vol. X, No. 09/I/Puslit/Mei/2018: 19-24.

Sukardi. (1993). Bimbingan karir di sekolah-sekolah. Jakarta: Ghalia Indonesia.

Sridasweni, A.Muri Yusuf, A. S. (2017). Abstrak. Bimbingan Dan Konseling, 6(2), 176-193.

Undang-undang Republik Indonesia Nomor 20 tahun 2003 tentang Sistem Pendidikan Nasional.

Jakarta:

Sekretariat Jenderal Departemen Pendidikan Nasional.

Utaminingsih, Yulianto, A., \& Aulia, R. (2013). Accounting analysis journal. Accounting Analysis Journal, 2(4), 413-422.

Widjayanto, Febby. (2018). Menyikapi Era Disrupsi. https://news.detik. com/kolom/d-3926626/ menyikapi-era-disrupsi. Diakses 02 April 2019.

Yarmis. (2012). Persiapan untuk bekerja Oleh: Yarmis Syukur Universitas Negeri Padang. Jurnal Ilmiah Ilmu Pendidikan, XII(2), 1-5. 